\title{
A Recipe for Promoting Economic Growth and Higher Living Standards in the 21st Century
}

Richard J. Cebula*

Walker/Wells Fargo Endowed Professor in Finance, Jacksonville University, Jacksonville, Florida 32211 USA

*Corresponding author: Richard J. Cebula, Walker/Wells Fargo Endowed Professor in Finance, Jacksonville University, Jacksonville, Florida 32211 USA, Tel: +912-656-2997; E-mail: dr.richardcebula@gmail.com

Rec Date: Sep 23 2014; Acc Date: Sep 26 2014; Pub Date: Oct 22014

Copyright: (c) 2014 Cebula RJ. This is an open-access article distributed under the terms of the Creative Commons Attribution License, which permits unrestricted use, distribution, and reproduction in any medium, provided the original author and source are credited.

\section{Editorial}

Following the Great Global Recession, some economies rebounded in a reasonably adequate fashion, while others have grown only very slowly. Arguably, for example, Germany belongs in the former category whereas the U.S. falls into the latter category. Why would such large industrial nations respond so differently to the same global economic environment? Recent research dealing with member nations of the OECD provides potentially very useful insights for a policy recipe for promoting economic growth and prosperity in the global economy of the 21 st century. The principal ingredients in this recipe are provided in this paper.

One critical ingredient to successful policy is to limit tax burdens. Higher tax burdens reduce disposable income and limit the ability to purchase new goods and services and thereby reduce/restrict the level of economic activity and the growth rate thereof. Nations such as the U.S. and France, for example, have elevated income tax rates at the highest levels of taxable income and have failed to stimulate their economies.

Another key to success is to limit budget deficits. Higher budget deficits crowd out private sector investment, reduce advances in $R \& D$, invention, innovation, and efficiency and thereby reduce the ability to compete in the global marketplace, quashing job growth in the process. The only genuinely appropriate time to incur a deficit increase is when income tax rates are cut in an intelligent and efficient fashion. The latter will stimulate long term growth and eventually elevate revenues to cove the deficit that financed them. Large budget deficits used largely to finance transfer payments, such as those undertaken by the U.S., damage the economy in the long run and do little to benefit the economy in the short run. Deficit reduction accomplished through reduced waste and reduced bureaucracies is an efficient way to cut deficits, especially since government bureaucrats tend to be paid far higher salaries than their private sector counterparts.

Another key ingredient to successful government policy is, when and if government regulation is legitimate, to pursue high quality regulation. The latter, when undertaken and nonpolitical, promotes sound policies and regulations that enable and promote private sector development, which in turn increases economic efficiency and thereby promotes economic growth.

Yet another ingredient is to promote economic freedom. Central to Adam Smith's (1776) Wealth of Nations is the idea that the basic institutions that protect the liberty and freedom of individuals to pursue their own economic interests will tend to result in a greater prosperity for society as a whole. In both the protection of and promotion of economic freedom in its various forms, not only will the individuals with greatest initiative receive the market/economic rewards they have earned, i.e., to which they are entitled, but also the economy of which they are a part will benefit as well. Individuals in an economically free society would be free and entitled to work, produce, consume, and invest in any way they please under a rule of law, with their freedom at once protected and respected by the state. Labor market freedom, property rights freedom, business freedom, and a host of other freedoms must be protected from an intrusive government, the forces of corruption, and the abuses of monopoly and monopsony.

Finally, the pursuit of monetary policies which avail adequate financing to the private sector based on efficiency and equality of opportunity will promote the establishment of efficient market interest rates to allocate funds to their highest and most socially beneficial use. 